\title{
Basal cell carcinoma in the eyelid region
}

\author{
J. R. O. COLLIN \\ From the South-East Thames Regional Plastic Surgery Unit, Queen Victoria Hospital, East Grinstead
}

The first recorded account of the surgical treatment of basal cell carcinoma is given by Jacques Daviel in an address to the Royal Society of London in I755 (Bennett, 1974). He described four patients with ulcers in the 'great angle' of the eye and four patients with ulcers affecting the eyelids, all of whom he treated successfully with surgical excision. Stenbeck (1900) was the first to describe the cure of a basal cell carcinoma with irradiation and during this century much literature has been published showing increasingly successful results with both forms of treatment. Older, Quickert, and Beard (1975) finally approached the ultimate with a report of 157 cases of histologically proved eyelid basal cell carcinoma, none of which recurred during a follow-up period that varied between a few months and 18 years. The purpose of this paper is to assess a series of eyelid basal cell carcinomas which were operated on in a general plastic surgery unit and to draw attention to the risk involved if the primary treatment does not effect a complete cure.

\section{Findings}

\section{INCIDENCE}

Between 1965 and 1970, 261 patients had histologically proved basal cell carcinomas removed from the eyelid region at the South-East Thames Regional Plastic Surgery Unit. This represents an average of 43.5 patients a year. Payne (r966) assessed that the average incidence of carcinoma of the eyelids for this area of England was 6.5/100 000 males and 4.1/100 000 females. This means that this unit was surgically treating the expected incidence of eyelid tumours for a population of approximately one million people. However, there are obviously gross inaccuracies in the collection of skin cancer statistics in view of the numerous treatments available by different medical practitioners, and the lack of statutory necessity to report cases to the Cancer Registry.

Altogether 226 of these patients had notes available for follow-up study and they had 255 separate eyelid basal cell lesions. 10.6 per cent of patients, therefore, had more than one eyelid tumour and the percentage would have been higher if other regions had been

Address for reprints: c/o The Librarian, Queen Victoria Hospital, Holtye Road, East Grinstead, Sussex included. These figures agree with those of Macomber, Wang, and Sullivan (1959) and Leventhal and Messer (1972). In this series three patients with multiple lesions had the naevoid basal cell carcinoma syndrome with dentigerous cysts.

\section{SITE}

The highest incidence was at the medial canthus and lower lid which agrees with Battle and Patterson (r960), Hayes (1962), and Payne (1966), but Holmström, Bartholdson, and Johanson (1975) and Older and others (1975) found there was a higher incidence on the lower lid than in the medial canthal area.

$\begin{array}{lc}\text { Site } & \text { Percentage } \\ \text { Upper lid } & 6 \cdot 7 \\ \text { Lower lid } & 37 \cdot 6 \\ \text { Medial canthus } & 38 \cdot 4 \\ \text { Lateral canthus } & 7 \cdot 1 \\ \text { Eyebrow } & 9 \cdot 4 \\ \text { Orbit } & 0.8\end{array}$

\section{SEX}

60.2 per cent were males and 39.8 per cent females. This is supported by Payne ( 1966$)$, Holmström and others (1975), and Brewitt, Hansen, and Huerkamp (1975), but Shulman (1962) and Older and others (1975) found that the sex incidence was about equal.

AGE

The peak incidence in this series was between 60 and 69 years $(36.9$ per cent of males and $31 \cdot 3$ per cent of females). This is in general agreement with Shulman (1962), Payne (1966), Fitzpatrick (1972), Rakofsky (1973), Meythaler (1973), Brewitt and others (1975), and Older and others (1975).

\section{SIZE}

Most of the lesions were between $5 \mathrm{~mm}$ and $2 \mathrm{~cm}$ in diameter, the highest incidence being between $I$ and $2 \mathrm{~cm}$. The average size of the lesions in the series of Fitzpatrick (1972) was $12 \mathrm{~mm}$, but in the series of Holmström and others (1975) the average largest diameter was less than $10 \mathrm{~mm}$. The recurrence rate was highest in cases of large tumours and this was confirmed 
by Battle and Patterson (1960), Von Essen (1960), Fitzpatrick (1972), and Older and others (1975).

$\begin{array}{ll}\text { Size of lesion } & \text { Percentage } \\ \text { Unspecified } & 10 \cdot 2 \\ \text { 'Small' or less than } 5 \mathrm{~mm} & 15 \cdot 0 \\ \text { Between } 5 \text { and } 10 \mathrm{~mm} & 33 \cdot 6 \\ \begin{array}{l}\text { Between } 1 \text { and } 2 \mathrm{~cm} \\ \text { More than } 2.5 \mathrm{~cm} \text { to } \\ \quad \text { complete orbital }\end{array} & 37.6 \\ \quad \text { involvement } & \\ \end{array}$

TYPE OF SURGERY

All lesions were excised with a 3 to $5 \mathrm{~mm}$ macroscopic clearance of the lesion depending on the individual surgeon, and the defect was closed by:

$\begin{array}{lc}\text { Method } & \text { Percentage } \\ \text { Direct closure } & 29 \cdot 8 \\ \text { Graft } & 9 \cdot 8 \\ \text { Flap } & 60 \cdot 4\end{array}$

All lesions were subjected to histological examination and if this showed an incomplete excision the patient was re-operated on. Such patients are not included in the figures given for recurrences.

\section{HISTOLOGY}

Most lesions were of the circumscribed common solid type and there was no very clearly defined pattern in the histology of those cases which recurred. However, 70 per cent of the lesions which did recur were described as morphoeic, invasive, or multicentric; 50 per cent of the recurrences occurred with medial canthal lesions. This is supported by Wiggs (1975).

\section{FOLLOW-UP PERIOD}

The aim with primary lesions in which histological examination had confirmed a complete excision, was to follow-up the patient for five years and in most cases this was achieved. Some patients, however, died, emigrated, failed to attend, or were followed-up by their own ophthalmologist, general practitioner, or dermatologist, and it is likely that many of these cases would have been referred back to this unit if they had developed a recurrence.

$\begin{array}{lr}\text { Time } & \text { Percentage } \\ \text { Less than 6 months } & 16 \cdot 5 \\ \text { 6 months to I year } & 6 \cdot 3 \\ \text { I-3 years } & 21 \cdot 3 \\ \text { 3-6 years } & 45 \cdot 2 \\ \text { 7-1 I years } & 10 \cdot 7\end{array}$

\section{Results}

\section{PRIMARY SURGERY}

Altogether 176 patients presented for surgery having had no previous treatment. Four of these patients $(2 \cdot 3$ per cent) had a recurrence and of these four, two of the histology reports showed complete clearance and the third did not specifically comment on the clearance. The recurrences in these three patients were all detected at routine follow-up and successfully excised. The fourth patient had a massive lesion involving both upper lids and extending across the bridge of the nose. He was referred for surgery from Ireland in view of the gross size of his carcinoma, and it seems surprising that he had not had any previous treatment but there was no record of this in his notes. He had an exenteration of one eye with removal of part of the malar bone, and excision of the medial third of the other upper eyelid. The histology report did not comment on clearance, presumably because much of the lesion had to be removed piecemeal. The carcinoma recurred four years later and an extensive resection of half of his face was undertaken, but clearance was incomplete and he died two years later.

\section{PREVIOUS IRRADIATION}

16.8 per cent or 38 patients out of the 226 in the series were referred for surgery with either a primary irradiation failure, a recurrence after irradiation, or an irradiation-induced lesion. 18.4 per cent $\left(7 / 3^{8}\right)$ had a recurrence after surgery. Three of these seven patients had basal cell carcinomas which were reported as having been completely excised. The re-recurrence was detected at routine follow-up and successfully excised. Three other patients died of their basal cell carcinomas and the fourth is expected to die soon. This means that in this series if a lesion recurred after irradiation and was not cured at the first attempt with subsequent surgery, there was a $57 \cdot \mathrm{I}$ per cent chance of dying of the disease. It must however be conceded that of these four patients, two who died had gross lesions involving the whole orbit, the third had a $1.5 \mathrm{~cm}$ lesion in the medial canthal area and the fourth, who is expected to die shortly, had multiple multicentric basal cell carcinomas after nine courses of $x$-ray treatment of the face for acne in 1936. In all of these patients histological clearance of the lesion was suspect.

\section{PREVIOUS SURGERY}

Ten patients out of the 226 (4.4 per cent) presented for surgery between 1965 and 1970 with a recurrence after primary surgery. Three of these patients (30 per cent) had a re-recurrence and of these, two subsequently died of their basal cell carcinomas. One had had the lesion removed twice previously by ophthalmologists; on referral he had an exenteration and the specimen was reported as being morphoeic with complete clearance. The rerecurrence occurred five years later and with subsequent surgery it was not possible to obtain complete clearance. The other patient who died 
was only 24 years old when referred with multiple morphoeic basal cell carcinomas which had recurred after previous surgery. $\mathrm{He}$ had multiple operations and histologically the lesions were initially completely excised but recurrent lesions kept appearing. The third patient, who had a successful excision of the re-recurrence, was a known case of the naevoid basal cell carcinoma syndrome.

\section{PREVIOUS COMBINED SURGERY AND IRRADIATION}

Two patients came into this category, one of whom subsequently died of his disease. The first patient had had two previous courses of radiotherapy and one episode of surgery for an upper eyelid basal cell carcinoma. She had an enucleation on referral, histological examination showed complete clearance, and she has had no recurrence during a $5 \frac{1}{2}$-year follow-up. The second patient similarly had had two courses of radiotherapy and one episode of surgery for an inner canthal lesion. An extensive excision was carried out on referral which showed a morphoeic basal cell carcinoma apparently completely excised. The lesion recurred seven months later and was re-excised again with complete clearance histologically, but it again recurred six months later and this time was inoperable.

\section{Discussion}

A recurrence rate of $2 \cdot 3$ per cent during an average follow-up period of between three and six years for cases of basal cell carcinomas treated with primary surgery is in general agreement with the figures reported in other series: Rank and Wakefield (1958), I.4 per cent; Hayes (1962), 3 per cent; Cobbett (1965), 3 per cent; and Binns and Sherriff (1975), 0.5 per cent. Older and others (1975), who reported a Ioo per cent cure rate, attributed their success to the use of frozen section controls in 72 per cent of their cases. This certainly does seem to improve the chances of successful surgery but whether this is feasible for every patient in view of the good results anyhow obtainable with primary surgery, depends very much on the facilities available.

Beard (1975) has drawn attention to the unpredictable nature of basal cell carcinoma recurrence in relation to the histological clearance. In this series if a lesion was incompletely excised the patient was re-operated on, but in 8.4 per cent the histological examination showed a suspect clearance and in none did a recurrence develop. Conversely in 4.4 per cent of this series the histological examination showed complete clearance and there was a sub- sequent recurrence. Rakofsky (1973) operated on 95 patients in 47 of whom the histological study showed incomplete clearance. Of these 47 , only 23.4 per cent actually developed a recurrence. Since we do not know which cases are going to recur we must aim at histologically-confirmed complete surgical excision. In this series it is unlikely that frozen section control would have improved the cure rate for cases treated with primary surgery in view of the fact that the recurrences in three cases occurred despite apparent complete clearance on routine histological examination.

Recently published recurrence rates of eyelid basal cell carcinoma treated with primary irradiation are of the same order as the recurrence rates after primary surgery: Fitzpatrick (1972), 4.8 per cent; Casanovas, Pĩnol, Oller, and Guix (1973), 2 per cent. The recurrence rate of 18.4 per cent for surgery to basal cell carcinomas which recur after irradiation is in general agreement with the recurrence rates reported by Rank and Wakefield (1958), 15.8 per cent; Hayes (1962), 24 per cent; Cobbett (1965), 20.5 per cent; and Sundell, Gylling, and Solvio (1966), 15.4 per cent.

The recurrence rate of 30 per cent for secondary surgery to lesions which have recurred after previous surgery is high, but 70 per cent of these patients in this series were referred from other areas of the country with extensive lesions. Von Essen ( 1960$)$ reported a 22 per cent overall recurrence rate for previously treated skin carcinomas which were subsequently given radiotherapy, and this is of the same order of magnitude.

\section{Conclusion}

This series shows that the worst prognosis for basal cell carcinoma occurring in the eyelid region is carried by large lesions in the medial canthal area which have recurred after previous treatment with surgery or irradiation; histologically they are classified as morphoeic, multicentric, or invasive. 3.5 per cent of the patients in this series died of their disease. Eyelid basal cell carcinoma is therefore a potentially lethal condition and whatever form of treatment is undertaken should be meticulously performed because there is no doubt that the first treatment gives by far the best chance of success.

I wish to thank the surgeons of the Queen Victoria Hospital, East Grinstead, for permission to examine the notes of their patients and in particular Mr R. L. Beare for his help and encouragement. My thanks are also due to Mrs Becky Law for typing this paper.

\section{References}

Battle, R. J. V., and Patterson, T. J. S. (1960) Brit. F. plast. Surg., 13, I I 8

BEARD, C. (1975) Trans. Amer. Acad. Ophthal. Otolaryng., 79, 664

BENNETT, J. P. (1974) Brit. F. plast. Surg., 27, 144 
BINNS, J. H., and SHERRIFF, H. M. (1975) Ibid., 28, 133

BREWitt, H., hanSEN, M. K., and HUERKamp, B. (1975) Klin. Mbl. Augenheilk., 166, 503

Casanovas, J., Pĩnol, J., Oller, f., and guix, J. R. (1973) Arch. Soc. esp. Oftal., 33, 667

COBBETT, J. R. (1965) Brit. F. Surg., 52, 347

FITZPATRICK, P. J. (1972) Radiology, I04, 66 I

HAYES, H. (1962) Plast reconstr. Surg., 30, 273

HOLMSTRÖM, H., BARTHOLDSON, L., and JOhANSON, B. (1975) Scand. F. plast. reconstr. Surg., 9, 107

LeVenthal, H. H., and MESSER, R. J. (1972) Amer. F. Surg., 124, 522

MACOMBER, W. B., WANG, M. K. H., and Sullivan, J. G. (1959) Plast. reconstr. Surg., 24, 545

MEYTHALER, H. (1973) v. Graefes Arch. Ophthal., 187, I I I

older, J. J., Quickert, M. H., and BIARd, c. (1975) Trans. Amer. Acad. Ophthal. Otolaryng., 79, 658 PAYNE, P. M. (I 966) CANCRO, 19, 268

RaKofsKy, S. I. (1973) Ann. Ophthal., 5, 596

RANK, B. K., and WAKEFIELD, A. R. (1958) Brit. F. Surg., 45, 53 I

SHUlMaN, J. (1962) Brit. F. plast. Surg., 15, 37

stenbeck, T. (1900) Mitt. Grenzgeb. Med. Chir., 6, 347

SUNDEll, B., GYlling, U., and solvio, A. I. (1966) Acta chir. scand., 131, 249

VON ESSEN, C. F. (1960) Amer. F. Roentgenol., 83, 556

wiggs, E. O. (1975) Trans. Amer. Acad. Ophthal. Otolaryng., 79, 649 